\title{
A Morphological Analysis of Slang Words Used by Characters in "Ralph Breaks the Internet" Movie
}

\author{
${ }^{1}$ Norah Bt Entus Nasrudin Tubagus, ${ }^{2}$ Siti Suharsih, ${ }^{3}$ Rahman Hakim \\ ${ }^{1,2,3}$ University of Sultan Ageng Tirtayasa, Serang, Banten \\ (Norah.Nune@gmail.com)
}

Article History: Submitted February $16^{\text {th }}, 2021$; Accepted May $28^{\text {th }}, 2021$; Published June $14^{\text {th }}, 2021$

\begin{abstract}
The current study entitled "A Morphological Analysis of Slang Words Used by Characters In Ralph Breaks the Internet Movie" aimed to investigate the morphological processes of constructing slang words and its meaning of the found slang words used by the movie characters. This research used a descriptive qualitative method with content analysis design. The findings revealed that there are 42 slang words categorized into different morphological processes included compound (14,28\%), clipping $(11,90 \%)$, blending $(14,28 \%)$, affixations $(16,66 \%)$, reduplicative $(7,14 \%)$, backformation $(2,4 \%)$, abbreviation $(2,4 \%)$, conversion $(4,76 \%)$, alternation $(14,28 \%)$, extension $(4,76 \%)$ and word manufacture $(7,14 \%)$. This study demonstrated the meaning changes of the slang words that have been affected through certain morphological processes by modifying their word category. Consequently, some slang terms have preserved the original meaning despite the changes in their spelling. In the meantime, certain slang words get abbreviated or shortened and retained their original meaning. Meanwhile, some slang words change their meaning by deriving their word category. Besides, there were certain slang words that change their meaning depending on word usage.
\end{abstract}

Key words: morphology, Ralph Breaks the Internet, slang

\begin{abstract}
Abstrak. Penelitian yang berjudul "Analisis Morfologi Kata-kata Slang yang Digunakan oleh karakter dalam Film 'Ralph Breaks the Internet'” bertujuan untuk menelaah proses morfologi dalam membangun kata-kata slang dan maknanya yang digunakan dalam film tersebut. Penelitian ini menggunakan metode kualitatif deskriptif dengan desain analisis isi. Data temuan menunjukkan 42 kata slang yang dikategorikan ke dalam proses morfologi yang berbeda, yaitu 'compound' (14,28\%), 'clipping' (11,90\%), 'blending' (14,28\%). , 'affixations' (16,66\%), 'reduplicative' (7,14\%), 'backformation' (2,4\%), 'abbreviation' $(2,4 \%)$, 'conversion' $(4,76 \%)$, 'alternation' $(14,28 \%)$, 'extension' $(4,76 \%)$ dan 'word manufacture' (7,14\%). Studi ini mendemonstrasikan perubahan makna dari kata-kata slang yang telah dipengaruhi proses morfologi tertentu dengan memodifikasi kategori kata asal. Hasilnya beberapa istilah dalam kata slang tetap mempertahankan makna aslinya meskipun ejaannya berubah. Sementara itu, kata-kata slang tertentu disingkat dan tetap mempertahankan arti aslinya. Beberapa kata slang lainnya berubah makna dengan mengubah kategori katanya. Selain itu, beberapa kata-kata slang tertentu berubah maknanya tergantung dari penggunaan kata.
\end{abstract}

Kata kunci: morfologi, Ralph Breaks the Internet, slang

\section{INTRODUCTION}

Slang language is an informal or nonstandard vocabulary complexation that was created by the society that sends an alternative social meaning. Coleman (2004: 2) has confirmed that 
slang words are often belong to a special age or follow a specific fashion to define the group identity which usually defined as a short-lived word. Regarding to that, these words came from the society who needs some new words to express themselves in a new, creative, different, funny word which allows people to be different, shocking, and friendly.

Besides, since slang words tend to appear quite frequently. It could appear as new meanings for existing words, or brand new words, or abbreviations for words. Mattiello (2008) has pointed out that slang words have a specific word formation system called morphology, which is a way or formula in forming new words contained new meaning such as affixation, conversion, compounding, clipping, reduplication, abbreviation, and variation. There are some words which have been through a specific morphological process to form a new meaning for example, yolo, which means "You Only Live Once" this process called abbreviation since the word has been shortened and only the first letters appear. Workaholic also is combination of two words which refers to a new meaning "work addicted", through morphological process called blending. There are many other English slang words as fleek, bae, selfie, salty, slay, ghost, and butthurt which been through many word processes such as compound, clipping, backformations and etc.

Moreover, Booij (2007:24) has confirmed that morphology is the study of the inner structure of words, work with the lexemes forms (inflection) and the way how these lexemes are formed (word-formation). Therefore, new words have been formed on the basis pattern of meaning form correspondence with existing words. The pattern in constructing new words through morphological processes described as a morphological rule, which functions as a specification of the predictable properties of complex words in the lexicon, and to indicate how new words can be form.

O'Grady \& Archibald (2016: 102) also defined that the smallest unit in language that has meaning and its function called morpheme. While lexeme is a basic lexical unit in linguistic that contained of one or several words and combined it with other words to form meaning. In contrast, word was defined as the smallest free form in a language including its variation that being affected by affixes. Moreover, O'Grady (1996: 471) \& Booij (2007: 3 ) agreed that words with its inflected variation are cited from a base or root (lexeme), For example walk, walked, and walking. These words are taken from the lexeme or the base walk. Based on Booij assumption, the construction of creating new word follows a specific pattern in order to create a new meaning. Therefore, this research examines the slang words in "Ralph Breaks the Internet" movie to investigate the slang words meaning and how these words have been constructed since the character were placed in informal situations.

The movie "Ralph Breaks the Internet" reached a high rate in Box Office since this movie nominated for the Oscar award as the best animated feature film. The content of movie shared positive messages with educational value so that many teachers often show the film as one of the media learning, especially for acquiring new languages and enhancing listening comprehension. As the matter of fact, most of the language used in this movie are slang words and it makes the audience can't understand the meaning of words easily. It is needed to figure out the meaning of the words by providing the process of the words formation based on morphological process. Therefore, researchers tend to analyse the slang words that appears in the movie by analysing its morphological processes to investigate the meaning of slang words whither its accepted to be used in real life, or it contains inferior or impolite meaning behind it. 
Studies on slang language have been done by several researchers such as Mahnunik (2015). The researcher's study with the title "An Analysis of Slang Language in Song Lyrics Used By "Justin Bieber" demonstrates the result of the morphological processes in constructing slang words in Justin Bieber's song lyrics. She used a qualitative descriptive research in explaining her obtained data. Siti has classified the found slang words using Gorge Yule's (2006) theory which is mostly used in categorizing standard words. She has categorized twenty four slang words into its morphological type whether there are coinage, clipping, borrowing, compounding, backformation, acronyms, multiple processes, affixation, or blending. In contrast, this research used different object, an animation movie, to examine and analyse whether slang words that used in the movie had a derogatory meaning or have become a common utterance to be used and accepted by the society. Furthermore, the research was based on Mattiello's (2008) book, which is a specialized theory for slang or informal language. Besides, slang theory differs from the basic grammatical theory since slang has some irregular and extra grammatical form or pattern that most of the informal words follow it.

Another previous research conducted the same filed with different object has been done by Panjaitan (2017). She has classified the slang words from Zootopia movie by a regular word formation process and categorized it based on Yule theory. She has a similar reveal with this research but she mainly focused on analysing the slang words based on the social factors or relations between the characters. While this research essentially focused on word construction as a morphology aspect, comprehend the hidden meaning in detail, and emphasize its real meaning. Therefore, this research aims to find out the meaning of the slang words used in "Ralph Breaks the Internet" movie and to determine the morphological process of each slang words used in "Ralph Breaks the Internet" movie.

\section{METHOD}

The purpose of this study was to discover the existences of the slang words that appear in "Ralph Breaks the Internet" Movie. This study applied qualitative approach, utilized content analysis method, and used descriptive analysis for the findings. Qualitative design as Ary.et.al (2010: 424-425) mentioned about, was applied in this research since it involves collecting and analysing non-numerical data in order to understand a specific concepts, issues, and experiences. It can be used to explore in depth about a problem or to generate new idea for a research.

Moreover, this study used content analysis method as an instrument in collecting valid data which is a series of activities to obtain data in a specific phenomenon. As Ari et al (2010: 242) pointed out that the objective of using content analysis in qualitative research is to systematically transform a large amount of text into a highly organised and concise summary of key results. Therefore, this research has been analysed descriptively to gain a detailed and valid data and to present the finding of the study with rich description of the wanted objects.

Regarding to that, this research used two instruments in collecting data, human instrument and documentation guideline as well. The guideline table that has been used in collecting the data was as follows: 
Table 1 The Design of Documentation Guideline

\begin{tabular}{|c|c|c|c|c|}
\hline No. & Duration & Slang word & $\begin{array}{c}\text { Meaning } \\
\text { (based on dictionaries) }\end{array}$ & $\begin{array}{l}\text { Morphological process } \\
\text { (based on theories) }\end{array}$ \\
\hline 1. & . & & & \\
\hline
\end{tabular}

The researchers used the instruments as a guideline in obtaining data from "Ralph Breaks the Internet" movie script by comprehending the dialogues between the characters and discovering the meaning through several dictionaries to find the real meaning of each slang word. While the second guideline table used to analyze and categorize the morphological processes of the found slang words based on Mattiello's theory. The terms that do not belong to morphological processes are avoided or omitted.

In this study, the data have been analyzed using an interactive model by Miles and Huberman (1994: 10-11). This technique consists of three concurrent flows activity. They are data reduction, data display, and conclusion drawing or verification. First, the data were collected and reduced from the movie script accordance to the desire objects and the limitation of this study. Second, the data displayed, organized, and categorized into a table which contained the morphological processes that had been found in the movie such as compound, blending, clipping, abbreviation, variation, affixation, reduplicative, conversion, back formation, and word manufacture based on the documentation guideline. Finally, the finding data are discussed, verified, and concluded accordance with the research objects. At the end, the researchers used trustworthiness which is a set of standards that demonstrate the conducted study quality to prove its ethical and competence. These standards used to convince the reader about the conducted study that has a credible result to be potentially useful to guide further research and investigation. Lincoln and Guba (as cited in Heigham and Croker (2009:264) claimed that a trustworthy study is a type of studies that deserves to be paid attention to. Therefore, the final result of the study is then verified to a linguistic expert in order to add credibility and quality to the research.

\section{RESULTS AND DISCUSSION}

This study discovered 42 slang words with different morphological processes which proposed by Mattiello (2008) theories. These words are categorized as slang words that used commonly in public or in informal situations. Even though some of these words has a rude meaning but still accepted by the public.

This study found that a few slang words have a closer or similar meaning to the original word before it gets derived into another term. Meanwhile, some slang words has a different meaning after being derived and changed its word class within morphology processes. In addition, the researchers also found some slang words that does not change its real meaning, but only gets abbreviated. Most of these slang words has different meaning with different usage.

Besides, the researchers found many slang words that categorized into different morphological processes with different terms based on the word class. Some founded slang 
words followed the basic processes of morphology which been used to form a word in standard English. Although, the researchers also found some slang words that been constructed through an extra-grammatical process that violated the basic morphological grammar properties which can be used only in forming slang words. The following table shows the finding data

Table 2 The Finding of the Slang Words That Appeared in the Movie

\begin{tabular}{|c|c|c|c|}
\hline No. & Slang word & Meaning & Morphological process \\
\hline 1 & Stink brain & $\begin{array}{l}\text { A person with unpleasnt } \\
\text { smell }\end{array}$ & \\
\hline 2 & Mouth breathing & Stupid person & \\
\hline 3 & Tapped out & Run out of money & Compound \\
\hline 4 & Dad joke & Silly joke & \\
\hline 5 & Holycow & An expression of surprice & \\
\hline 6 & Pied pipers & Convying person & \\
\hline 7 & Butt & Buttoks & \\
\hline 8 & Gee-whiz & Jesus & \\
\hline 9 & Tech & Technician & \\
\hline 10 & Chum & Chamber & \\
\hline 11 & Fella & Fellow & \\
\hline 12 & Pigloo & Pillow and igloo & Clipping \\
\hline 13 & Hobo & Poor worker & \\
\hline 14 & Doohickey & Small forgetten named item & \\
\hline 15 & Chumbo & Fat friend & \\
\hline 16 & Buttload & A large amount of something & \\
\hline 17 & Grandma & Grand mother & Blending \\
\hline 18 & Weirdos & Weird person & \\
\hline 19 & Bonkers & Crazy & \\
\hline 20 & Youngstes & Group of children & \\
\hline 21 & Dummy & Stupid person & \\
\hline 22 & Buster & $\begin{array}{l}\text { Disrespectful expression for } \\
\text { addresing a man }\end{array}$ & Affixation \\
\hline 23 & Bellyaching & Complaining & \\
\hline 24 & Darn tootin' & 3Strongly agree & \\
\hline 25 & Get got & get killed & \\
\hline 26 & Looky looky & Asking for attention & Reduplicative \\
\hline 27 & Humpty dumpty & Fat person & \\
\hline 28 & Scamps & $\begin{array}{l}\text { A person with a likable } \\
\text { misbehavior }\end{array}$ & Back formation \\
\hline 29 & BFF & Best frinds forever & Abbreviation \\
\hline 30 & Hand it & Asking & \\
\hline 31 & spice things & $\begin{array}{l}\text { Add some excitment to a } \\
\text { thing }\end{array}$ & Conversion \\
\hline 32 & Pal & Friend & \\
\hline 33 & Folks & $\begin{array}{l}\text { A friendly form to address } \\
\text { people }\end{array}$ & \\
\hline 34 & Sassy & Stylish and slightly arrogant & \\
\hline 35 & Buddy & Friend & \\
\hline 36 & Peeps & People & Variation (alternation) \\
\hline 37 & Dope & Excellent & \\
\hline 38 & Thingamabobs & $\begin{array}{l}\text { Used as a term for something } \\
\text { the name of which is } \\
\text { unknown, forgotten or not }\end{array}$ & Variation (extension) \\
\hline
\end{tabular}




\begin{tabular}{llll}
\hline & & important. & \\
39 & Nope & No & \\
40 & Moolah & Money & Word manufacture \\
\hline 41 & Bingo & Winning & \\
42 & Galoot & a clumsy or oafish person & \\
\hline
\end{tabular}

The researchers explain in detail a few examples of the founded slang words from the movie due to its abundance.

\section{Compound}

It is a type of morphological process or a mechanism in which two words are combined to produce one word with a different meaning (Mattiello, 2008: 72).

$$
\text { For example } \quad \text { : (mouth Breathing) }
$$

Morphological Rule : Mouth (n) + Breathe (v) +ing ( derivational suffix)

Deverbal

$\rightarrow$ Mouth breathing (n)

As shown above, the word breathe classified as a verb which followed by a derivational suffix that changes the part of speech from being a verb as in the word "breathe" into a noun to create a deverbal word "breathing". Thus, when the word "mouth" is added to the deverbal word "breathing", it consequently changes the word into an expression to indicate a fool or stupid person. There was also another word categorized as compound such as stink brain, tapped out, holy cow, and pied pipers.

\section{Clipping}

A morphological process where words with more than one syllable are reduced to a shorten form by dropping some of its part (Mattiello, 2008: 141).

$$
\begin{array}{ll}
\text { For example } & :(\text { tech }) \\
\text { Morphological Rule } & : \text { technician }(n)+\text { back-clipping }(\text { nician }) \rightarrow \text { tech }(n)
\end{array}
$$

The word "tech" was constructed through a morphological process in which the beginning of a base lexeme is retained named back-clipping process. The final term of the original word "technician" has been dropped to create a simple slang word that retained its original meaning which does not have a rude sense. Many words appeared as clipped word in this movie, for instance, butt, gee-whiz, fella, and chum.

\section{Blending}

Blending is a morphological process of forming words by merging parts of the words into one word. It varies based on its part, it could be a partial (part of the word retained), prototypical (parts of both word being merged), or overlap blends (same letters being overlapped). (Mattiello, 2008: 138). 


$$
\begin{array}{ll}
\text { For example } & \text { : (buttload) } \\
\text { Morphological rule } & \text { : buttocks (head) }+ \text { load (base) } \rightarrow \text { buttload }
\end{array}
$$

The word buttload in which the head of a word is followed by a base belongs to morphologically partial blending. This process combines two words with unrelated meaning to form a new meaningful word that has been categorized as a slang word in the Routledge slang dictionary (2018:115) to indicate a large amount of something. Besides, many slang words have been founded in the movie such as pigloo, hobo, chumbo, doohickey, and grandma.

\section{Affixation}

Affixation or derivation is a morphological process that derives a word class by adding either prefixes, suffixes or infixes to construct a new word or lexeme (Mattiello, 2008, pp. 91-123).

$$
\begin{array}{ll}
\text { For example } & :(\text { weirdo }) \\
\text { Morphological rule } & : \text { weird }(\operatorname{adj})+O(\text { deriv suffix })=\text { Weirdo }(\mathrm{n})
\end{array}
$$

The above process explained that derivational process usually used to form a personal noun from an adjective that refers to a person's quality especially in a negative way as in the word "dumbo" which means a stupid person. The word "weirdo" refers to a person who acts strangely or weird based on Cambridge dictionary and Routledge Slang Dictionary (2018, p 838). Moreover, the (suffix -O) is categorized as an extra grammatical process, since this morphological formation could only construct slang words. (Mattiello, 2008:66). besides, the researchers found many slang words specified as derivation words such as Bonkers, Youngsters, dummy, buster, bellyaching, and darn tootin.

\section{Reduplicative}

Reduplicative is a common morphological process whereas word or part of it being repeated on a specific rhyming (Mattiello, 2008: 131). The researchers found 3 slang words which belong into a different specification as ablaut, rhyming compound, rhyming reduplicative, and copy reduplicative which is frequently used in constructing slang words.

$$
\begin{aligned}
& \text { For example } \quad: \text { (get got) } \\
& \text { Morphological Rule : get (verb) + got (past verb) } \rightarrow \text { get got (verb) }
\end{aligned}
$$

From the above morphological rule, it shows that the only changes in this word is the phoneme /e/ in the word get and /ä/ in the second word got in which both of them are categorized as vowels. Thus, if there was any vowel changes or replacement in a specific process called ablaut or aphonic reduplicative as it has been pointed out in Mattiello theory (2008:131). Each word has a different meaning when it stands separately. The word "get" tends to refer an act of earning, having, or acquiring, while the word got denotes something had earned. Therefore, the result of combining these two words created a whole new lexeme "get got" with different meaning which used to point out to a hostile act ended by killing the person. There are also other slang words appeared as a reduplicative word in this movie such as looky-looky, and humpty dumpty. 


\section{Back Formation}

The process backformation derives a word class by dropping the last actual suffix of a word to construct a new meaning of new lexeme. (Mattiello, 2008: 129).

$$
\begin{array}{ll}
\text { For example } & : \text { (scamps }) \\
\text { Morphological Rule } & : \text { scamper }(\mathrm{v})+\text { clipped }- \text { er }(\text { inflectional suffix })+ \\
& -s(\text { inflectional suffix }) \rightarrow \text { Scamps }(\mathrm{n})
\end{array}
$$

The word "scamp" has been formed from the word scamper which refers to someone who runs with light feet based on the Cambridge dictionary, while the word scamps meant children who misbehave in a likable way or amusing way. The meaning and the function of the word have changed due to a morphological process that been used to this word.

\section{Abbreviation}

An abbreviation is a process in which a word is invented from a set of words by retaining the initial letters of the words (Mattiello, 2008:135). The researchers found one abbreviated slang word which been categorized depends on its spelling whether its acronym or initialism.

$$
\begin{array}{ll}
\text { For example } \quad:(\mathrm{BFF}) \\
\text { Morphological Rule }: \text { Best }(\mathrm{n})+\text { Friend }(\mathrm{n})+\text { Forever }(\mathrm{n}) \rightarrow \mathrm{BFF}
\end{array}
$$

The specific process of the word BFF was categorized as an initialism based on Mattiello's theory (2008:137) in which the words' letters being pronounced individually or separately. This slang word became common to be used in informal situations by people around which refers to a strong relationship with friends according to Cambridge dictionary of slang and the Routledge dictionary (2018: 47).

\section{Conversion}

Conversion or zero affixation process is where a word gets derived to a different word class without corresponding formal changes (Mattiello, 2008:124).

$$
\begin{aligned}
& \text { For example } \quad:(\text { Hand it) } \\
& \text { Morphological Rule : Hand }(\mathrm{n})+i t \text { (pronoun) } \rightarrow \text { hand it }(\mathrm{v})
\end{aligned}
$$

This word uses zero affixation to form a new word with different class without changing its original word form. The word "hand it", has different meaning when it gets separated or stands individually. Based on Cambridge online dictionary, the word "hand it" describes a thing to be given for someone successful or skilful.

\section{Variation}

Variation is one of the common ways in forming a slang word which modifies a word base by varying its spelling or part of it. Although, it covers range of processes as morphology and phonology. The word variation has different processes such as analogy, malapropism, metathesis, letter pronunciation, alternation, and extension (Mattiello, 2008: 150). 
For example $\quad:$ (thingamabobs)

\section{Morphological Rule : thing (n) + amabob (meaningless suffix) + $\boldsymbol{S}$ (inflectional suffix) $\rightarrow$ thingamabobs}

According to Cambridge, Urban and Routledge Slang Dictionary (2018: 788), the word "thingamabob" is similar as the word "dooheckey" which is a noun used to describe items that either can not be remembered or items that its not even exist. While In morphology, the above morphological rule was categorized as irregular morphological process based on Mattiello theory (2008: 154) in which it alternates another word by adding one or more syllables that not corresponded or meaningless to any existing suffixes. this extragrammatical process of slang word formation is a branch of alternation called extension. however, many words have been found in this movie which categorized as a variation such as pal, folks, sassy, buddy, peeps, dope, and nope.

\section{Word Manufacture and Fanciful}

The process of word manufacture happened when the word gets invented or formed by the society to indicate a specific thing which could be from a specific product, place, or even a person name with no morphological motivation. Meanwhile, fanciful formation denotes Some words that have unrecognized or unknown origin. (Mattiello, 2008: 154). Also, Yule (2010: 53) has claimed that coinage was a process where the words being invented and tend to become an everyday word in a language which called neologism. For example, in the word "moolah", the slang formation of the word "moolah" was a fanciful formation due to its unknown origin. Although, the slang word "moolah" was frequently used in the old ages even by Hall Ellson, the author of the "duke" novel in 1949s as it mentioned in Routledge dictionary which means money. However, many words refer to money that has been invented by the society such as Mazoola, Moo, and Bucks. Moreover, there were many coined words that appeared in the movie such as Galoot, and Bingo.

As this research discussed, the common process that has been found by the researchers in this movie is compound $(14,28 \%)$ since it could link two words or two morphemes in order to form a new lexeme such as the words pied piper, tapped out, holy cow, dad joke, mouth breathing, and stink brain. These words had classified as a compound with different type of compound depends on the word class based on Mattiello theory. Besides, most of those words have listed by Routledge and Urban Dictionary of slang which indicates that those slang words are commonly used by the society even when some of it has a rude meaning but still accepted by the public.

Moreover, there were also some words that belongs to another type of processes including blending $(14,28 \%)$ and clipping $(11,90 \%)$. The blended words where their morphemes were merged with another word were the word pigloo, chumbo, hobo,grandma and buttload, while the words that distinguished as a clipped word were tech, and butt. However, the researchers found a word that has been clipped and merged at the same time based on Mattielo theory was the word dooheckey.

Furthermore, the researchers have found other slang words that exist from deriving the original word to form a new meaning such as the word spice things up, and hand it which claimed as a conversion $(4,76 \%)$ where the base class has changed without any addition. Meanwhile, there was another type of derivation that called affixation that forms a new meaningful word by adding either suffixes or prefixes. The researchers have categorized 
the words youngsters, bonkers, buster, darn tootin', bellyaching and weirdos as words that being affected by any terms of affixes that changes the word meaning.

Although, regarding to morphological processes in constructing slang words, Mattielo (2008) claimed that abbreviations included Initialism and acronyms $(2,4 \%)$ are categorized as a way to abbreviate a word and differs on the way it spelled. The researchers found the word TED and $H Q$ that classified as an acronym but not categorized as a slang word, therefore the researchers did not include it in this research. Meanwhile, the word $B F F$ was assorted as a slang based on several slang dictionaries. Moreover, the researchers have found a word that labeled with back-formation process $(2,4 \%)$ as the word scamps in which a word has been derived from the original word scamper which its meaning was not related with the new lexeme.

Along with morphology, the researchers have found a complicated process that has unpredictable word clipped and spelling alternation of clipping. The researchers found a word that been clipped from the word technician in which the last term has been dropped to form the word tech. Meanwhile, some back clipping change its phonem as the word fella. However, some words even could change its spelling after they got clipped as the word peeps, and gee-whiz. These words had categorized as a slang words that been through two processes with different aspect called morphonological where the clipped words were related with its phonems.

In addition, reduplication or repitation $(7,14 \%)$ are a common way in forming slang or colloquial words using this term where the words being copied with different rhyms as the words looky-looky and humpty dumpty, both words are categorized as a reduplicatons but with different formula of constructing based on Mattillo theory and supported by O'Grady $\&$ Archibald, Booig and Plag theories.

Besides, there are several words have found in this movie with irregular morphological slang word formation processes. Thus, those words were classified as a type of language variation which modifies the word base or part of it by respelling the slang word. A type of language variation called alternation $(14,28 \%)$ that has many branches in forming slang words, for example the word buddy that originated and alternate the word brother, the word sassy originated from the word saucy, and the word peeps that alternate the word people, and even the word dope has been used as an alternation of many words based on the situations.

However, there was another type of alternation in which forms a slang words by adapting words from other languages such as the word pal, and folks. Although, word extensions $(4,76 \%)$ were listed also as a word alternation that been found in the word nope which denotes the word no, and in the word thingamabobs which followed with irregular suffix to alternate the word dooheckey.

In fact, the resarcher found some words that appeared with no morphological or founded rule. This type of irregular morphological process called word manufactor or fanciful formation $(7,14 \%)$ in which the word being invented with no morphological motivation such as the word bingo, moolah and galoot however, the researchers have found many slang words that involved into another aspect of linguistic. For instance, as the words wanna, gonna, kinda, gotta, ain't and heyo which seems that belongs to morphology since it blends two diffrent word class but it generated more as a phonological term called elision. Besides, trimmed words as " $\mathrm{em}$ " from the word them, and the $n$ sound in any 
word with suffix -ing that has appeared in the word rollin' and lookin are not involved to either morphological processes. Thus, these words are allocated to phonolgy in which it studies about how the sounds being merged. Moreover, there are some slang words that inspired from a specific sound named onomatopeia or echoism to indicate something such as the word kacing that refers to money, barf to describe something nasty and boom that expresses a win or success, which all are involved under phonology term.

In addition, the resaercher has omitted some idioms that has found in the movie since it belongs to different aspect, as the phrases put on hours, sweet moter of monkey milk, old sun of gun and way to go. These are classified as lexical phrases in semantics as Mattiello has mentioned in her book. Meanwhile the word heck and gosh are categorized as an euphemistic words in which the words are derivided into an apropriate word to replace the word with a bad meaning. Idioms and euohemistic words are generilaized as a semantics aspect. Therefore, the researchers have averted the idioms or any term related with semantics.

Overall, the findings of the study determine the presence of slang words with different morphological processes in the movie. To respond to the first research question, the analysis revealed that some slang words have an closer or similar meaning to the original words, and some has a different meaning within the changes that caused by morphology processes. Meanwhile, some slang words were only simplified or abbreviated the original words and retained its meaning. This result further revealed that words could change its meaning in different situation and usage as Panjaitan (2017) has discovered that most of slang words occur based on the social factors or relations between the characters. To respond to the second research question, based on the findings it is revealed that many slang words are categorized into different morphological processes with different terms based on the word class. Some founded slang words followed the basic processes of mropholgy whicn been used to form a word in standard English. Additionally, the researchers found some slang words has been constructed through an extra-grammatical process that violated the basic morphological grammar properties which can be used only in forming slang words.

\section{CONCLUSION}

After conducting this research, the finding reveals 42 slang words founded in "Ralph Breaks the Internet" movie categorized into 10 different morphological processes. Regarding to the meaning of slang words, this research shows that some meaning of slang words got changed due to the morphological process that affects into the word class. Some of these words retained or has a similar meaning with the original word, and some slang words were only simplified or abbreviated, and some changed its original meaning.

While in morphology, the researchers found all the type of slang words processes in "Ralph Breaks The Internet" movie which are compound $(14,28 \%)$, clipping $(11,90 \%)$, blending $(14,28 \%)$, affixation $(16,66 \%)$, reduplication $(7,14 \%)$, backformation $(2,4 \%)$, abbreviation $(2,4 \%)$, conversion $(4,76 \%)$, alternation $(14,28 \%)$, extension $(4,76 \%)$ and word manufacture $(7,14 \%)$ except three processes the researchers could not find it in this movie which are the extra grammatical processes including acronym, elliptic rhyming slang and reversed form. Among these morphological slang word-formation processes, affixation was the most frequent morphological process used in this movie than the others. 


\section{REFERENCES}

Ackema, P \& Neeleman, A. (2004). Beyond Morphology: Interface conditions on word formation. Oxford: Oxford University Press.

Allan, K. et. al. (2006). Forbidden Word. New York: Cambridge

Anney, V, N. (2014). Ensuring the Quality of the Findings of Qualitative Research: Looking at Trustworthiness Criteria. Journal of Emerging Trends in Educational Research and Policy Studies, 5(2), 272-281. Retrieved Feb 19, 2020, from https://docplayer.net/52099744-Ensuring-the-quality-of-the-findings-of-qualitativeresearch-looking-at-trustworthiness-criteria-author-vicent-naano-anney-1.html

Archibald, J., \& O'Grady, W. (2016). Contemporary linguistic analysis: An introduction $\left(8^{\text {th }} \mathrm{ed}\right)$. Toronto: Pearson.

Arikunto, S. (2017). Pengembangan Instrumen Penelitian dan Penilaian Program. Yogyakarta: Pustaka Pelajar.

Ary, D. Et al. (2010). Introduction to Research in Education $\left(8^{\text {th }}\right.$ ed). Canada: Nelson Education

Ayto, J. (1998). The Oxford Dictionary of Slang. New York, USA: Oxford University Press

Booij,G (2007). The grammar of words: an introduction to morphology (2 $2^{\text {nd }} e d$ ). New York, USA: Oxford University Press

Coleman, J. (2012) The life of slang. New York, USA: Oxford University Press Inc

Creswell, John W. (2012). Educational Research. Boston: Pearson Education Inc

Dalzell, T. (2018). The Routledge dictionary of modern English slang and unconventional English $\left(2^{\text {nd }} e d\right)$. New York: Routledge

Fathonah, E,L ( 2018) word formation and meaning of slang words on "meme" picture of group "shitpostbot 5000" on social media "facebook". Surabaya: University of Sunan Ample. http://digilib.uinsby.ac.id/id/eprint/25565

Green, J. (2005) The Vulgar Tongue: Green's History of Slang. New York, USA: Oxford University Press Inc

Heigham, J., \& Croker, R. A. (2009). Qualitative Research in Applied Linguistics A Practical Introduction. UK: Palgrave Micmillan.

Holmes, J. (2013). An Introduction to Sociolinguistics (4 ${ }^{\text {th }}$ ed). New York, USA: Routledge

Hotten, J,C. (1913 ) The Slang Dictionary: Etymological Historical and anecdotal. London, England: Chatto \& Windus

Hudson, R,A. (1996). Sociolinguistics ( $2^{\text {nd }}$ ed). NewYork, USA: Cambridge University Press. 
Jamet, D. (2009). A morphological approach to an English clipping. Lexis: Journal in English lexicology. https://doi.org/10.4000/lexis.884

Kehr, D (2020) Animation: Britannica Inc. Retrieved June 20, 2020, from https://www.britannica.com/art/animation

Kolowich, L. (2019). The Evolution of Language: How Internet Slang Changes the Way We Speak. Retrieved December 2, 2019, from https://blog.hubspot.com/ marketing/how-internet-changes-language

Kopp, J (n.d.). 5 Reasons slang language is important for language learning. Retrieved December 2, 2019, from https://www.omniglot.com/language/articles/whysla ngisimportant.htm

Mahnunik, S,N. (2015) An Analysis of Slang Language in Song Lyrics Used by Justin Bieber. Surabaya: University of Sunan Ampel. http://digilib.uinsby.ac.id/3715/

Mattiello,E.(2008). An Introduction to English Slang. Milano, Italy: Polimetrica.

Miles, M. B., \& Huberman, A. M. (1994). Qualitative data analysis: An expanded sourcebook $\left(2^{\text {nd }} e d\right)$. London: Sage

Munro, M. (2017) Chambers pardon my English!: an exploration of slang and informal language. Hopetoun Crescent, Edinburgh: Chambers Harap Publishers Ltd.

O'Conner, P,T. \& Kellerman, S. (2019, December 01). You're darn tootin'! Retrieved June 15, 2020, from https://www.grammarphobia.com/blog/2019/12/darn-tootin.html

O'Grady, W, et al. (1996). Contemporary Linguistics: An Introduction ( $3^{\text {rd }}$ ed). New York, USA: St. Martin Press.

Panjaitan, Tuti Alawiyah. (2017). An Analysis of Slang Language in Zootopia Movie. Malang: Maulana Malik Ibrahim University. http://etheses.uin-malang.ac.id/14154/

Plag, I. (2002). Word formation in English. Cambridge University Press

Thorne, T. (2007). Dictionary of contemporary slang ( $3^{\text {rd }}$ ed). London: A \& C Black Publisher Ltd

Wardhaugh, R. (2006). An introduction of sociolinguistics $\left(5^{\text {th }}\right.$ ed). UK: Blackwell Publishing Ltd

Yule, G. (2010). The Study of Language $\left(4^{\text {th }} e d\right)$. Cambridge: Cambridge University Press.

\section{WEBSITES}

https://dictionary.cambridge.org/

https://www.lexico.com/

https://www.merriam-webster.com/

https://www.urbandictionary.com/ 